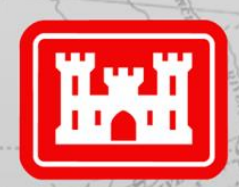

US Army Corps of Engineers ${ }_{\circledast}$

\title{
Comparison of Benthic Fish Assemblages along Revetted and Natural Banks in the Lower Mississippi River: A 30-Year Perspective
} MRG\&P Report No. 29 • January 2020

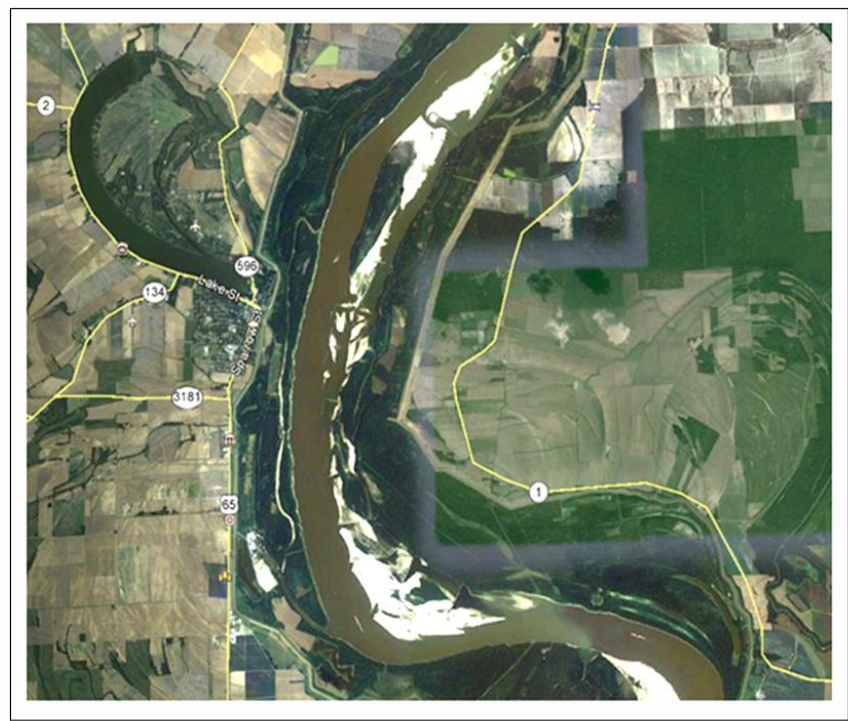

\section{MRG\&P}

Mississippi River Geomorphology \& Potamology Program 



\title{
Comparison of Benthic Fish Assemblages along Revetted and Natural Banks in the Lower Mississippi River: A 30-Year Perspective
}

\author{
K. Jack Killgore and Steven G. George \\ Environmental Laboratory \\ US Army Engineer Research and Development Center \\ 3909 Halls Ferry Road \\ Vicksburg, MS 39180-6199
}

Final report

Approved for public release; distribution is unlimited.

\footnotetext{
Prepared for US Army Corps of Engineers Mississippi Valley Division

Vicksburg, MS 39180

Under WAT 2019-3478
} 


\section{Abstract}

Benthic fish assemblages were compared in 2016-2017 among three different bank types in the Lower Mississippi River (LMR) using hoopnets: Articulated Concrete Mattress (ACM) along main channel banks, natural banks along main channel, and natural banks in a secondary channel. Species richness was highest in secondary channels (21 species), followed by ACM (20 species), and natural banks (16 species). However, abundance of dominant species (i.e., Flathead Catfish, Blue Catfish, Freshwater Drum, and Buffalo) differed seasonally. Blue Catfish were more abundant along natural banks and secondary channels during the summer. Flathead Catfish abundance peaked during the summer in the secondary channels but were also abundant along ACM year-round. Freshwater Drum abundance was highest along natural banks in the winter and ACM in the spring. Juvenile Buffalo utilized secondary channels in the winter indicating the importance of these habitats for over-wintering fishes. Comparison of the native benthic fish assemblage between 1985 and 2016-17 revealed minimal differences in species composition and abundance indicating long-term stability and resilience of LMR fishes. An exception was the prevalence of Asian Carp (Silver and Bighead), which were two to three times higher than any native species. 


\section{Contents}

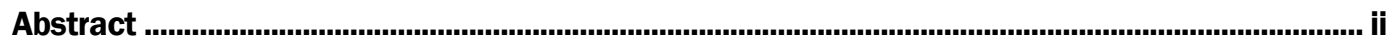

Figures and Tables.......................................................................................................................

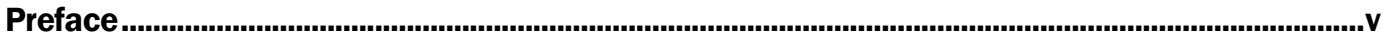

1 Introduction ............................................................................................................................... 1

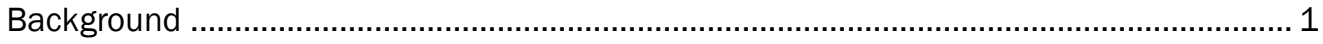

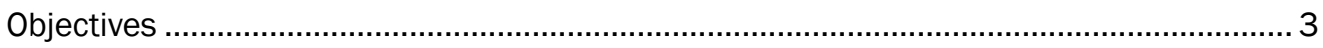

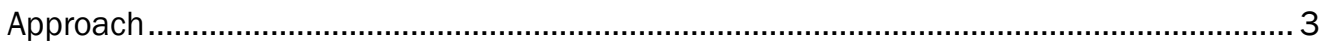

2 Methods ...................................................................................................................................... 4

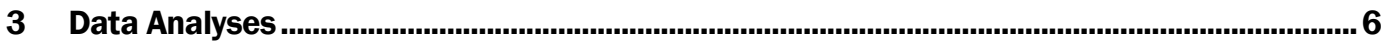

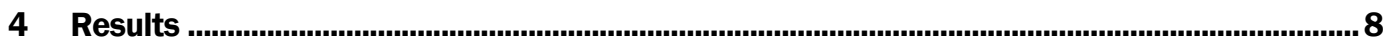

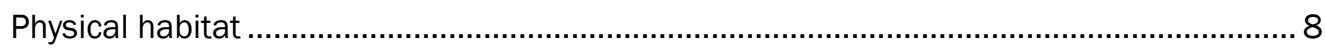

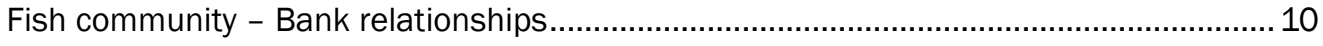

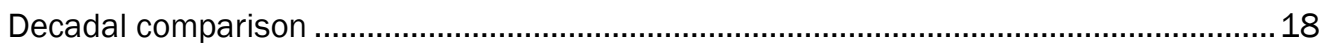

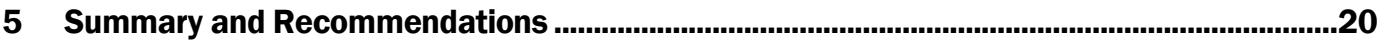

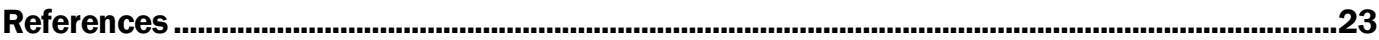

Unit Conversion Factors ..........................................................................................................25

Report Documentation Page 


\section{Figures and Tables}

\section{Figures}

Figure 1. Mat Sinking Unit operating on the Mississippi River; inset of ACM grooves......................... 2

Figure 2. Sampling locations on the Mississippi River.................................................................... 4

Figure 3. Hydrograph during the 2016-17 sampling period. Red dots indicate sampling events (source: Rivergages.com).

Figure 4. Comparison of mean CPUE (overnight sets of hoopnets) of fish in the LMR between 1985 ( $n=10$ each habitat) and 2016-2017 ( $n=15$ for ACM and $n=14$ for Natural Banks).

\section{Tables}

Table 1. Summary of water quality variables measured in the Island 82 reach, LMR, from December 2016 to November 2017.

Table 2. Summary of physical habitat variables measured at each hoopnet in the Island 82 reach, LMR, from December 2016 to November 2017.

Table 3. Number of individuals collected during the 2016-17 study by hoopnet size and habitat. Species are arranged in phylogenetic order.

Table 4. Pairwise PERMANOVA by habitat type of the 4th root transformed resemblance matrix (Bray-Curtis Similarity) of all fish species collected by 3 and $4 \mathrm{ft}$ hoopnets in the LMR.

Table 5. Mean CPUE \pm 1 standard deviation of fish species collected by $3 \mathrm{ft}$ hoopnets in the LMR during 2016 and 2017. Values with letters in the column are significantly $(p<0.05)$ different among seasons within a habitat based on a mixed model ANOVA.

Table 6. Mean CPUE \pm 1 standard deviation of fish species collected by $4 \mathrm{ft}$ hoopnets in the LMR during 2016 and 2017. Values with letters in the column are significantly $(p<0.05)$ different among seasons within a habitat based on a mixed model ANOVA.

Table 7. Mean CPUE \pm 1 standard deviation of Asian Carp collected by $4 \mathrm{ft}$ hoopnets in the LMR during 2016 and 2017. Values with letters in the column are significantly $(p<0.05)$ different among seasons within a habitat based on a mixed model ANOVA.

Table 8. Mean length (millimeter) of fish species collected in the LMR, 2016-2107. All values are total length except Shovelnose Sturgeon (fork length) and Paddlefish (eye-tofork length). 


\section{Preface}

The research documented in this report was conducted as part of the Mississippi River Geomorphology and Potamology (MRG\&P) Program, under WAT 2019-3478. The MRG\&P Program is part of the Mississippi River and Tributaries Project and is managed by the U.S. Army Corps of Engineers (USACE), Mississippi Valley Division (MVD), and districts. At the time of publication of this report, the MRG\&P Program Director was Dr. James W. Lewis. The MVD Commander was MG R. Mark Toy. The MVD Director of Programs was Mr. James A. Bodron.

The work was performed by the Aquatic Ecology and Invasive Species Branch of the Ecosystem Evaluation and Engineering Division, U.S. Army Engineer Research and Development Center, Environmental Laboratory (ERDC-EL). At the time of publication of this report, Mr. Alan Katzenmeyer was Branch Chief; Mr. Mark Farr was Division Chief; and Dr. Al Confrancesco was the Technical Director for ERDC-EL. The Deputy Director of ERDC-EL was Dr. Jack Davis, and the Director was Dr. Ilker Adiguzel.

Mr. Bill Lancaster (JAYA and ERDC-EL) assisted in hoopnet collections. Ms. Amanda Oliver (GSI and ERDC-EL) produced the map. This technical report was reviewed by Dr. Jan Jeffrey Hoover and Dr. Catherine Murphy, ERDC-EL, and Dr. James Lewis, MVD.

The Commander of ERDC was COL Teresa A. Schlosser, and the Director was Dr. David W. Pittman. 


\section{Introduction}

\section{Background}

The Lower Mississippi River (LMR) meanders within the confines of the mainline levee system for almost 1,00o miles to the Gulf of Mexico creating two major types of riverbank habitat. The concave side of the meander loop typically has high velocities forming steep (30 degrees to almost vertical), erosional banks consisting of consolidated clays and silts (Baker et al. 1988). The convex side is depositional due to lower water velocities forming large, primarily sand pointbars. The river straightens between meander loops as the thalweg crosses the channel with both types of bank habitats present along its course.

The erosional nature of concave banks leads to channel instability that could impact minimum commercial navigation depth and undermine nearby levees. Therefore, the Mississippi River and Tributaries (MR\&T) Project authorized the construction of almost 1,000 miles of revetment to stabilize river banks (Benjamin et al. 2016). Banklines are cleared of trees and woody debris, graded to a lower slope ( $<30$ degrees), riprap is placed near the top bank, and Articulated Concrete Mattress (ACM) is laid from the top bank to the edge of the channel up to water depths of 120 feet (ft) (Baker et al. 1988). Articulated Concrete Mattress is formed by linking concrete blocks with corrosion resistant wires into units and deployed from a vessel known as the Mat Sinking Unit, a vessel uniquely designed for this purpose (Figure 1 - Mat Sinking Unit). Each block is $4 \mathrm{ft}$ long, 18 inches (in.) wide, and 3 in. thick and each linked unit is $25 \mathrm{ft}$ long by $4 \mathrm{ft}$ wide (Pokrefke 2012). Horizontal grooves are formed in each concrete block to increase the surface area for macroinvertebrate attachment (Baker et al. 1988). 
Figure 1. Mat Sinking Unit operating on the Mississippi River; inset of ACM grooves.

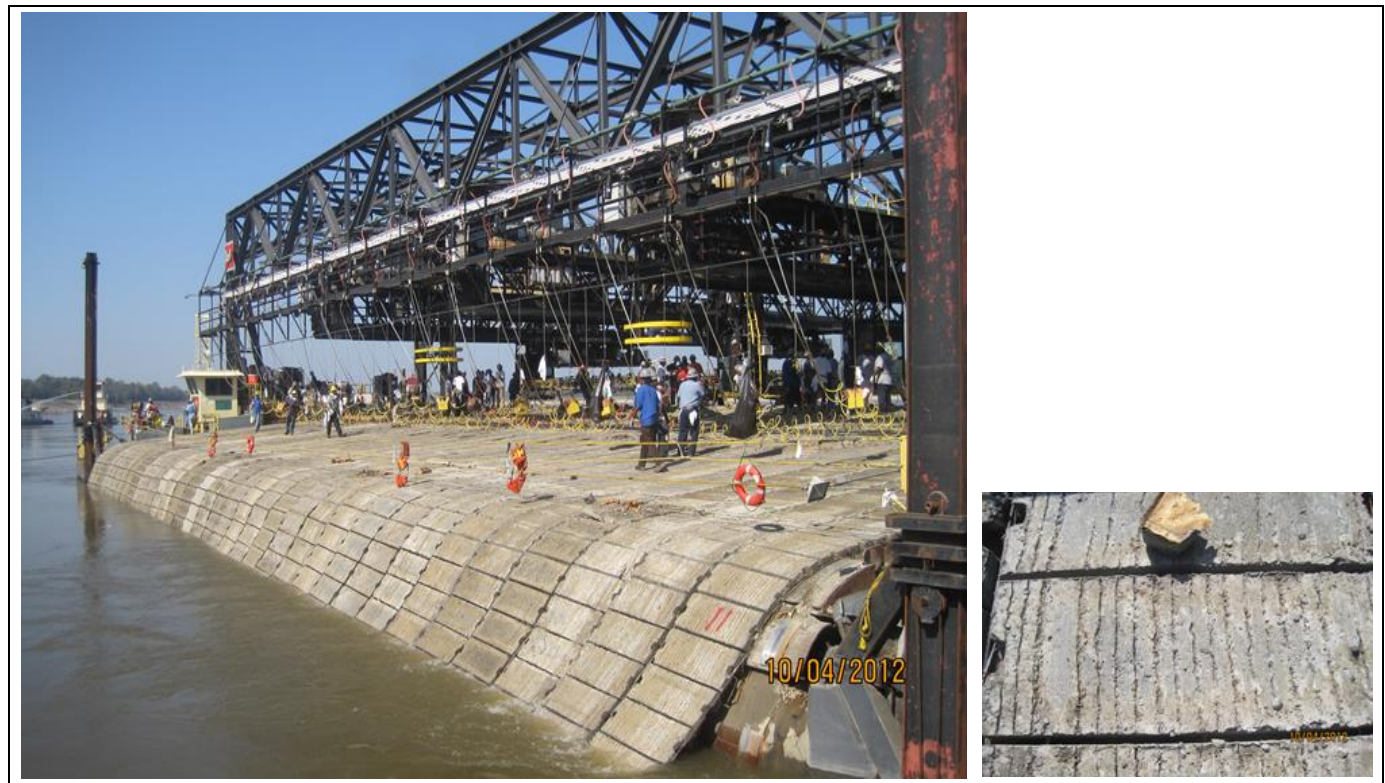

The conversion of natural steep banks to ACM has ecological consequences. The aquatic invertebrate fauna shifted from burrowing mayflies (i.e., Pentagenia vittiqera and Tortopus incertus) to net-spinning caddisflies (primarily Hydropsyche orris) (Baker et al. 1988). The effect on fish foraging is unknown. In addition, the loss of trees and woody debris from bank clearing and stabilization, as well as snag removal operations in the early to mid-1900s, reduced instream habitat complexity and substrates for macroinvertebrate colonization. The benefits of woody debris on habitat quality and aquatic biodiversity are well established in the literature (Wondzell and Bisson 2003).

ACM does provide a supplemental hard substrate sometimes used by gravel-spawning riverine fishes. Pallid Sturgeon were documented with sonic telemetry spawning over revetted banks in the Missouri River (DeLonay et al. 2016). ACM tends to buckle over time, creating depositional areas that increase substrate heterogeneity in high-velocity habitats, and forms crevices used as velocity refugia by rheophilic fishes and macroinvertebrates. Periphyton has been observed covering ACM in shallow, lower-velocity habitats, which based on previous studies, is grazed upon by small invertebrates, fishes, and other aquatic animals and contributes considerably to the productivity of aquatic ecosystems, natural or human-made (Azim 2009). 


\section{Objectives}

Physical, chemical, and biological surveys were made along three revetted and two natural banks in the LMR during the summer and fall of 1985 (Baker et al. 1988). This was the first ecological study of riverbanks along the LMR. The present study was initiated to compare benthic fish assemblages among riverbank habitats over a 30-year time period (1985 and 2016-17). The same collecting gear (i.e., $3 \mathrm{ft}$ diameter hoopnet) was used in both studies. The 2016-17 study also included $4 \mathrm{ft}$ diameter hoopnets to target larger benthic fish and evaluate the relative abundance of Asian Carp (Hypophthalmichthys sp.) in the collections. In addition, the 2016-17 study sampled secondary channel river banks because of their importance to the LMR Conservation Plan (Killgore et al. 2014) and Biological Opinion (USFWS 2013) as key habitats for the three endangered species in the LMR: Pallid Sturgeon, Fat Pocketbook Mussel, and Interior Least Tern.

\section{Approach}

The approach is presented in Chapter 2 Methods. 


\section{Methods}

Sampling with hoopnets occurred along the Island 82 reach in the LMR from River Mile 542 to 547 (Figure 2). The ACM and natural bank sites were positioned along the concave side of the main channel. The lower reach of Island 82 chute was sampled as the secondary channel site. The three sites were sampled two to three times seasonally from December 2016 to November 2017.

Figure 2. Sampling locations on the Mississippi River.

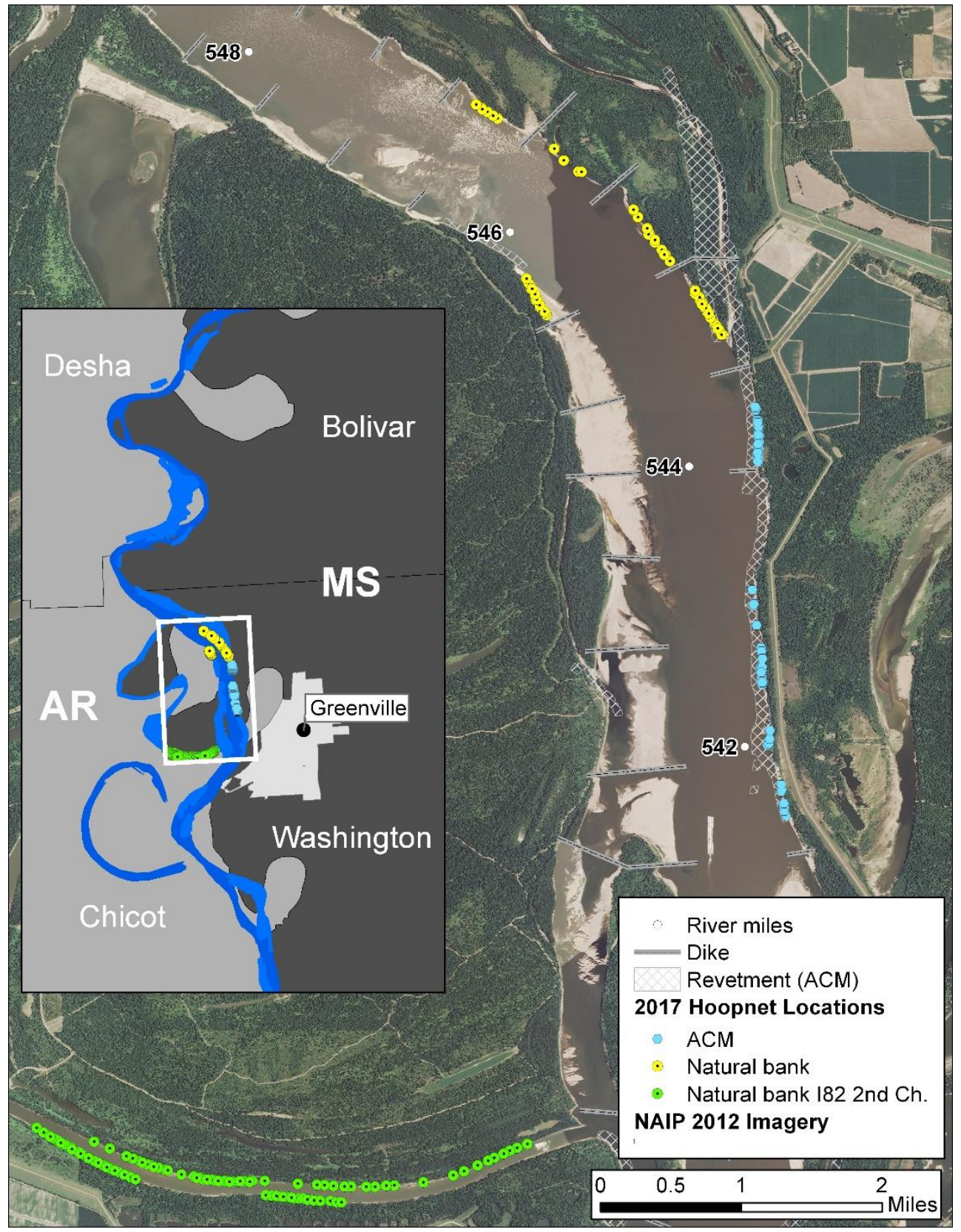


Hoopnets were constructed of fiberglass hoops and tarred nylon netting using 5/16 in. braided polypropylene. Two sizes of hoopnets were used targeting a wide range of benthic species: $3 \mathrm{ft}$ diameter opening, seven hoops, $10 \mathrm{ft}$ long, $1 \mathrm{in}$. square mesh; $4 \mathrm{ft}$ diameter opening, seven hoops, 13 $\mathrm{ft}$ long, 3 in. mesh. The former was used by Baker et al. (1988) in the original hoopnet study of LMR bank habitats. The latter are typically used by commercial fisherman in the LMR. All hoopnets were placed close to the bank to minimize confounding influences of water depth, water velocity, and distance from shore. Unbaited nets were deployed during the afternoons and retrieved the following morning, with an average ( \pm 1 standard deviation) soak time of $20 \pm 0.9$ hours. Fish were identified in the field, total length measured, and released.

Physical habitat measurements were taken at each hoopnet to characterize the fluvial environment associated with benthic fish assemblages. Depth was recorded with a transom-mounted depth finder; surface water velocity was recorded with a Marsh-McBirney Flo-Mate, Model 2000; distance from shore was measured with Bushnell ${ }^{\circledR}$ laser rangefinder (Pro16oo), and each hoopnet was georeferenced using a hand-held Garmin GPSMAP 64st (datum WGS 84). Water quality parameters were measured on the surface with a YSI Pro DSS once per trip near the center of each site and included dissolved oxygen (milligrams per liter), $\mathrm{pH}$, conductivity (microsiemens per centimeter), water temperature $\left(\mathrm{C}^{\circ}\right)$ and turbidity (Nephelometric Turbidity Unit). 


\section{Data Analyses}

Relative abundance (catch per unit effort [CPUE]) was compared among the three riverbank types, and the $3 \mathrm{ft}$ hoopnet collections in 1985 were compared with those from 2016-17. CPUE is defined as number of individuals per species or species guild caught per hoopnet night.

Different-size hoopnets were analyzed separately because size of fish entering the net and retention were dependent on mesh size and hoop diameter. Abundance data were 4th-root transformed to down-weight highly abundant taxa while still taking into account rare species, and a dummy variable $(\mathrm{n}=1)$ was added to each sample to mathematically adjust for sparsity within the data table (Goodsell and Connell 2002). A resemblance matrix of transformed species abundances was created by computing Bray-Curtis similarity indices for each assemblage comparison (Clarke and Gorley 2015). Differences in community composition among sites were tested on the resemblance matrix using a one-factor (fixed effect = habitat type) permutational multivariate analysis of variance (PERMANOVA) performed using PRIMER software, version 7 (PRIMERe, QUEST Research Ltd.). This test estimates, through permutation, a Pseudo-F statistic analogous to the univariate F-statistic and an associated $p$ value (Clarke et al. 2014). The test statistic of PERMANOVA indicates the significance value among the three different habitats. Similarity percentages were calculated (SIMPER, 80\% cutoff for low contributions) on CPUE values to determine which species contributed to the similarity pattern depicted among groups (i.e., typifying species), as well as those species that contribute to the dissimilarity between groups (i.e., discriminating species).

Differences in the abundance of individual species or taxonomic groups among habitats and seasons were analyzed using a mixed model analysis of variance (ANOVA) to account for repeated measures covariance structure because fixed stations were sampled over four seasons. Repeated sampling of the same sites violates the assumption of independence among observations. For this application, a mixed design partitioned the variation due to fixed sampling stations and the temporal autocorrelation that may occur among repeated measurements (Maceina et al. 1994). Sample size was partitioned by four seasons and nine sampling dates with five nets usually set in each habitat. In some instances, nets were lost or hung on debris. Mixed model calculated least squares means for nets per 
date, then averaged the value by seasons to account for unbalanced data. Least squares means in the mixed model were compared among habitat, seasons, and the interaction between the two. Least squares means were used to account for skewness due to zero-inflated data. Prior to ANOVA, CPUE was $\log$ transformed $(\log [\mathrm{x}+1])$ to stabilize variance and meet parametric assumptions. 


\section{Results}

\section{Physical habitat}

Sampling occurred on eight separate dates from December 2016 to November 2017 for the ACM and Natural Bank sites whereas the Secondary Channel site was sampled six times from February 2017 to November 2017. Water quality variables were comparable among sites (Table 1). Water temperature ranged from 5.5 to $30.8{ }^{\circ} \mathrm{C}$ across all four seasons. Dissolved oxygen measurements were always above 6 milligrams per liter (mg/L) and averaged near $9.0 \mathrm{mg} / \mathrm{L}$. Mean turbidity was slightly higher in the Secondary Channel site, possibly due to an increase in primary productivity, with maximum values for all sites near 100 NTUs during high river stages. Winter and spring samples were taken during a mostly rising hydrograph while summer and autumn samples were taken on a mostly falling hydrograph (Figure 3).

Table 1. Summary of water quality variables measured in the Island 82 reach, LMR, from December 2016 to November 2017.

\begin{tabular}{|c|c|c|c|c|c|c|}
\hline Habitat & $\mathrm{N}$ & $\begin{array}{c}\text { Water } \\
\text { Temperature } \\
{ }^{\circ} \mathrm{C}\end{array}$ & $\begin{array}{c}\text { Dissolved } \\
\text { Oxygen } \\
\mathrm{mg} / \mathrm{L}\end{array}$ & $\begin{array}{c}\text { Conductivity } \\
\mu \mathrm{S} / \mathrm{cm}\end{array}$ & $\mathrm{pH}$ & $\begin{array}{c}\text { Turbidity } \\
\text { NTU }\end{array}$ \\
\hline $\mathrm{ACM}$ & 8 & & & & & \\
\hline Mean & & 15.5 & 9.7 & 443.3 & 7.7 & 39 \\
\hline Std Dev & & 8.7 & 2.1 & 43.7 & 0.5 & 25.6 \\
\hline Minimum & & 5.5 & 6.1 & 373 & 6.9 & 17.4 \\
\hline Maximum & & 30.5 & 12.7 & 512 & 8.6 & 107 \\
\hline Natural Bank & 8 & & & & & \\
\hline Mean & & 15.5 & 9.8 & 442.7 & 7.7 & 38.7 \\
\hline Std Dev & & 8.9 & 2.2 & 44.8 & 0.5 & 26.2 \\
\hline Minimum & & 5.5 & 6.1 & 373 & 6.9 & 14.2 \\
\hline Maximum & & 30.5 & 12.7 & 512 & 8.6 & 107 \\
\hline Secondary Channel & 6 & & & & & \\
\hline Mean & & 18.2 & 8.7 & 427.3 & 7.4 & 49.3 \\
\hline Std Dev & & 7.8 & 1.9 & 38.2 & 0.2 & 24.5 \\
\hline Minimum & & 8.1 & 6.1 & 369 & 6.9 & 14.2 \\
\hline Maximum & & 30.8 & 12.3 & 490 & 8.6 & 98.8 \\
\hline
\end{tabular}


Figure 3. Hydrograph during the 2016-17 sampling period. Red dots indicate sampling events (source: Rivergages.com).

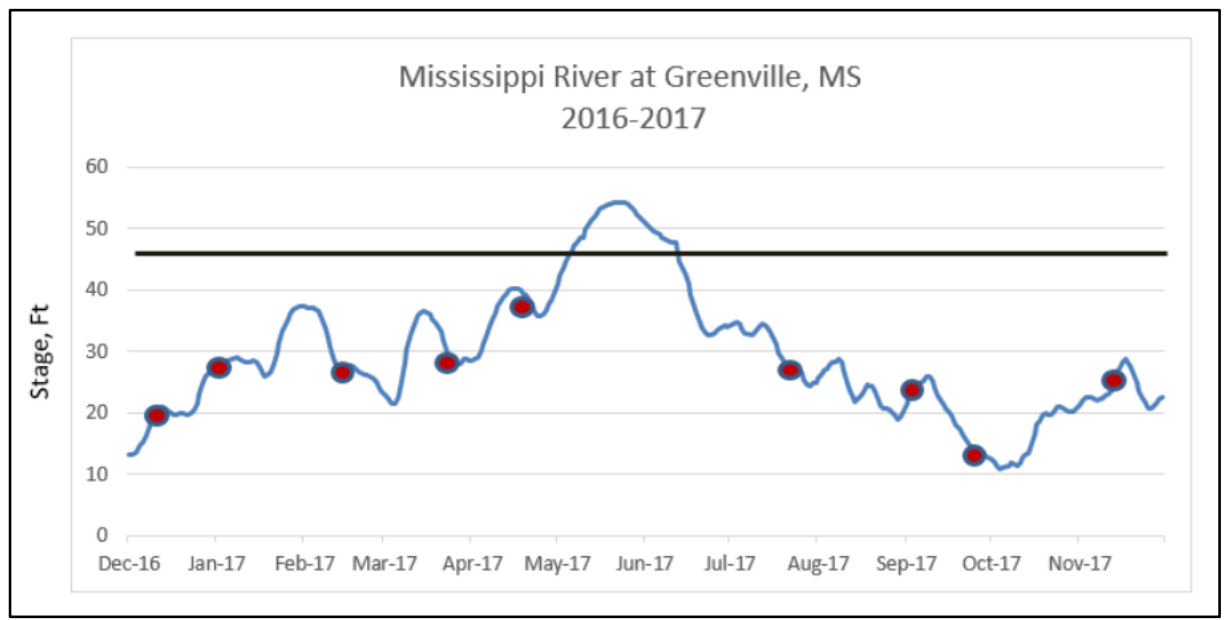

A total of 309 hoopnets were deployed and retrieved during the study comprised of $1553 \mathrm{ft}$ hoopnets and $1544 \mathrm{ft}$ hoopnets. The mean values of the five physical variables characterizing hoopnet habitat locations were comparable among sites (Table 2). Shoreline and submerged bank slope were slightly higher at the Natural Bank site; depth of net-sets averaged approximately 3.0 meters $(\mathrm{m})$; distance to shore was approximately $4.0 \mathrm{~m}$ on average, and mean surface water velocity ranged from a low of 47 centimeters per second $(\mathrm{cm} / \mathrm{s})$ at the Secondary Channel site to $69 \mathrm{~cm} / \mathrm{s}$ at the ACM site. Maximum surface velocity recorded was $116 \mathrm{~cm} / \mathrm{s}$ along ACM.

Table 2. Summary of physical habitat variables measured at each hoopnet in the Island 82 reach, LMR, from December 2016 to November 2017.

\begin{tabular}{|l|c|c|c|c|c|c|}
\hline Habitat & $\mathrm{N}$ & $\begin{array}{c}\text { Shoreline } \\
\text { Slope } \\
\text { Degrees }\end{array}$ & $\begin{array}{c}\text { Bottom } \\
\text { Slope } \\
\text { Degrees }\end{array}$ & $\begin{array}{c}\text { Depth } \\
\text { Meters }\end{array}$ & $\begin{array}{c}\text { Distance } \\
\text { to Shore } \\
\text { Meters }\end{array}$ & $\begin{array}{c}\text { Velocity } \\
\mathbf{c m} / \mathbf{s e c}\end{array}$ \\
\hline ACM & 100 & & & & & \\
\hline Mean & & 44.5 & 37.8 & 2.7 & 3.6 & 69.2 \\
\hline Std Dev & & 11.4 & 10.9 & 1.2 & 2.4 & 22 \\
\hline Minimum & & 15 & 15 & 1.0 & 0.6 & 14 \\
\hline Maximum & & 75 & 75 & 7.8 & 15.5 & 116 \\
\hline Natural Bank & 97 & & & & & \\
\hline Mean & & 54.4 & 39 & 2.9 & 4.7 & 57.3 \\
\hline Std Dev & & 20.4 & 15.4 & 1.4 & 3.2 & 21 \\
\hline Minimum & & 15 & 5 & 1.0 & 0.9 & 2 \\
\hline Maximum & & 90 & 75 & 8.8 & 18.9 & 111 \\
\hline
\end{tabular}




\begin{tabular}{|l|c|c|c|c|c|c|}
\hline Habitat & $\mathbf{N}$ & $\begin{array}{c}\text { Shoreline } \\
\text { Slope } \\
\text { Degrees }\end{array}$ & $\begin{array}{c}\text { Bottom } \\
\text { Slope } \\
\text { Degrees }\end{array}$ & $\begin{array}{c}\text { Depth } \\
\text { Meters }\end{array}$ & $\begin{array}{c}\text { Distance } \\
\text { to Shore } \\
\text { Meters }\end{array}$ & $\begin{array}{c}\text { Velocity } \\
\mathrm{cm} / \mathbf{s e c}\end{array}$ \\
\hline Secondary Channel & 112 & & & & & \\
\hline Mean & & 44.7 & 38.1 & 3.7 & 4.2 & 48.6 \\
\hline Std Dev & & 27 & 16.2 & 1.9 & 3.8 & 25 \\
\hline Minimum & & 0 & 0 & 0.9 & 0.9 & 3 \\
\hline Maximum & & 93 & 60 & 8.9 & 22.3 & 114 \\
\hline
\end{tabular}

\section{Fish community - Bank relationships}

A total of 26 fish species was collected during the study with 3 and $4 \mathrm{ft}$ hoopnets (Table 3 ). Only 18 species were collected in $4 \mathrm{ft} \mathrm{hoopnets}$ whereas 24 species were collected in $3 \mathrm{ft}$ hoopnets. Paddlefish and Bighead Carp were not collected in $3 \mathrm{ft}$ hoopnets; these large-bodied species likely avoided the smaller diameter and mesh of $3 \mathrm{ft}$ hoopnets. The eight species not collected in $4 \mathrm{ft}$ hoopnets were American Eel, Shortnose Gar, Longnose Gar, Goldeye, Mooneye, Longear Sunfish, White Crappie, and Sauger; larger mesh size probably allowed these smaller-bodied or tereteshaped species to escape.

Fish community structure differed significantly (Pseudo-F=1.852, $\mathrm{p}=0.045,999$ permutations) among the three habitat types using $3 \mathrm{ft}$ hoopnets (Table 4). Pair-wise tests indicated that community structure was significantly different between the secondary channel and ACM $(\mathrm{t}=1.6907, \mathrm{p}=0.013)$. Dissimilarity between these two habitats was due to greater number of species collected in the secondary channel but not found along ACM including Grass Carp, Longear Sunfish, Mooneye, Shovelnose Sturgeon, and Silver Carp (Table 3). Average faunal similarity percentages among the three habitats ranged $14.1 \%-20.1 \%$, indicating differences in overall species composition. However, the typifying or more common species collected in all three habitats comprising at least $50 \%$ of the abundance were Flathead Catfish, Blue Catfish, and Freshwater Drum. 
Table 3. Number of individuals collected during the 2016-17 study by hoopnet size and habitat. Species are arranged in phylogenetic order.

\begin{tabular}{|c|c|c|c|c|c|c|c|}
\hline \multirow[b]{2}{*}{ Fish Taxon } & \multicolumn{3}{|c|}{ HN3 } & \multicolumn{3}{|c|}{ HN4 } & \multirow[b]{2}{*}{ Total } \\
\hline & $\mathrm{ACM}$ & $\begin{array}{l}\text { Natural } \\
\text { Bank }\end{array}$ & $\begin{array}{c}\text { Secondary } \\
\text { Channel }\end{array}$ & $\mathrm{ACM}$ & $\begin{array}{c}\text { Natural } \\
\text { Bank }\end{array}$ & $\begin{array}{c}\text { Secondary } \\
\text { Channel }\end{array}$ & \\
\hline Scaphirhynchus platorynchus, Shovelnose Sturgeon & & & 1 & & & 1 & 2 \\
\hline Polyodon spathula, Paddlefish & & & & 1 & & & 1 \\
\hline Lepisosteus osseus, Longnose Gar & 2 & 3 & 2 & & & & 7 \\
\hline Lepisosteus platostomus, Shortnose Gar & 2 & & 2 & & & & 4 \\
\hline Hiodon alosoides, Goldeye & 5 & 2 & & & & & 7 \\
\hline Hiodon tergisus, Mooneye & & & 1 & & & & 1 \\
\hline Anguilla rostrata, American Eel & 1 & 1 & 2 & & & & 4 \\
\hline Dorosoma cepedianum, Gizzard Shad & 9 & 2 & & 4 & 2 & 1 & 18 \\
\hline Ctenopharyngodon idella, Grass Carp & & & 2 & 2 & & 2 & 6 \\
\hline Cyprinus carpio, Common Carp & 2 & & & 1 & & 4 & 7 \\
\hline Hypophthalmichthys molitrix, Silver Carp & & & 1 & 37 & 38 & 62 & 138 \\
\hline Hypophthalmicthys nobilis, Bighead Carp & & & & 2 & 3 & 9 & 14 \\
\hline Carpiodes carpio, River Carpsucker & & 1 & 2 & 11 & 3 & 5 & 22 \\
\hline Carpiodes velifer, Highfin Carpsucker & 1 & & & 5 & 3 & & 9 \\
\hline Cycleptus elongates, Blue Sucker & 1 & & 1 & 2 & 1 & 1 & 6 \\
\hline Ictiobus bubalus, Smallmouth Buffalo & 4 & 2 & 10 & 19 & 17 & 34 & 86 \\
\hline Ictiobus cyprinellus, Bigmouth Buffalo & 1 & & 3 & 7 & 8 & 6 & 25 \\
\hline
\end{tabular}




\begin{tabular}{|c|c|c|c|c|c|c|c|}
\hline \multirow[b]{2}{*}{ Fish Taxon } & \multicolumn{3}{|c|}{ HN3 } & \multicolumn{3}{|c|}{ HN4 } & \multirow[b]{2}{*}{ Total } \\
\hline & ACM & $\begin{array}{l}\text { Natural } \\
\text { Bank }\end{array}$ & $\begin{array}{l}\text { Secondary } \\
\text { Channel }\end{array}$ & ACM & $\begin{array}{c}\text { Natural } \\
\text { Bank }\end{array}$ & $\begin{array}{c}\text { Secondary } \\
\text { Channel }\end{array}$ & \\
\hline Ictiobus niger, Black Buffalo & 1 & & 1 & 4 & 2 & 3 & 11 \\
\hline Ictalurus furcatus, Blue Catfish & 4 & 14 & 14 & 1 & 6 & 2 & 41 \\
\hline Ictalurus punctatus, Channel Catfish & 7 & & 4 & 2 & 1 & 3 & 17 \\
\hline Pylodictis olivaris, Flathead Catfish & 18 & 14 & 32 & 10 & 5 & 1 & 80 \\
\hline Morone chrysops, White Bass & 4 & 1 & 3 & 5 & & 8 & 21 \\
\hline Lepomis megalotis, Longear sunfish & & & 1 & & & & 1 \\
\hline Pomoxis annularis, White Crappie & 1 & & 1 & & & & 2 \\
\hline Sander canadensis, Sauger & 1 & & & & & & 1 \\
\hline Aplodinotus grunniens, Freshwater Drum & 9 & 8 & 14 & 14 & 4 & 10 & 59 \\
\hline Total Number & 73 & 48 & 97 & 127 & 93 & 152 & 590 \\
\hline
\end{tabular}


No significant differences in fish community structure among habitats were detected using $4 \mathrm{ft}$ hoopnets (Pseudo-F=1.3416, $\mathrm{p}=0.176,999$ permutations, Table 4). Average faunal similarity among the three habitats ranged $17.3 \%-21.3 \%$. Silver Carp were most abundant in $4 \mathrm{ft}$ hoopnets, followed by buffalo (Smallmouth, Bigmouth, and Black) and Freshwater Drum. Abundance of other species was comparable among habitats. The primary difference between 3 and $4 \mathrm{ft}$ hoopnet collections was lower species richness and the presence and high abundance (approximately $20 \%$ of the total individuals) of Silver Carp in the larger hoopnets.

Table 4. Pairwise PERMANOVA by habitat type of the 4th root transformed resemblance matrix (Bray-Curtis Similarity) of all fish species collected by 3 and $4 \mathrm{ft}$ hoopnets in the LMR.

\begin{tabular}{|l|c|c|c|}
\hline \multicolumn{5}{|c|}{$3 \mathrm{ft}$ Hoopnets } \\
\hline Bank Habitats (Groups) & $\mathrm{T}$ & $\mathrm{P}$ (perm) & Unique Permutations \\
\hline Secondary Channel, ACM & 1.6907 & 0.013 & 999 \\
\hline Secondary Channel, Natural Bank & 1.0443 & 0.369 & 999 \\
\hline ACM, Natural Bank & 1.2252 & 0.192 & 999 \\
\hline \multicolumn{5}{|c|}{$\mathbf{4 f t ~ H o o p n e t s}$} \\
\hline Secondary Channel, ACM & 1.1972 & 0.231 & 999 \\
\hline Secondary Channel, Natural Bank & 1.2528 & 0.156 & 998 \\
\hline ACM, Natural Bank & 1.3266 & 0.147 & 998 \\
\hline
\end{tabular}

Back-calculated least square means provided the model-adjusted median value, which is a more appropriate measure of central tendency for skewed data. However, zero-inflated data resulted in a median approximating zero in all cases, so mean CPUE was reported in the tables (Tables 5 and 6). Statistical significant difference $(\mathrm{P}<0.05)$ in CPUE among seasons and habitats was denoted in the tables based on results of the mixed model.

Blue catfish abundance in $3 \mathrm{ft}$ hoopnets was significantly higher during the summer whereas there were no significant differences among habitats or the interaction between habitat and seasons. No significant differences were detected using $4 \mathrm{ft}$ hoopnets. Flathead catfish abundance was significantly higher in the summer at ACM and secondary channel sites in $3 \mathrm{ft}$ hoopnets, and only during summer on ACM in $4 \mathrm{ft}$ hoopnets. Smallmouth Buffalo abundance was significantly higher in secondary channels during the winter in $3 \mathrm{ft}$ hoopnets. No significant difference among habitats and seasons occurred for Buffalo in $4 \mathrm{ft}$ hoopnets 
indicating their ubiquitous distribution in the LMR. There were no significant differences among seasons and habitats for Freshwater Drum in $3 \mathrm{ft}$ hoopnets. However, Freshwater Drum were significantly more abundant in $4 \mathrm{ft} \mathrm{hoopnets} \mathrm{in} \mathrm{the} \mathrm{spring} \mathrm{at} \mathrm{all} \mathrm{three} \mathrm{habitat} \mathrm{types,} \mathrm{and}$ maximum abundance occurred along ACM.

Table 5. Mean CPUE \pm 1 standard deviation of fish species collected by $3 \mathrm{ft}$ hoopnets in the LMR during 2016 and 2017. Values with letters in the column are significantly $(p<0.05)$ different among seasons within a habitat based on a mixed model ANOVA.

\begin{tabular}{|c|c|c|c|c|c|c|}
\hline Habitat & Season & $\mathrm{N}$ & Blue Catfish & $\begin{array}{l}\text { Flathead } \\
\text { Catfish }\end{array}$ & $\begin{array}{c}\text { Smallmouth } \\
\text { Buffalo }\end{array}$ & $\begin{array}{c}\text { Freshwater } \\
\text { Drum }\end{array}$ \\
\hline \multirow[t]{4}{*}{ ACM } & Fall & 12 & 0 & 0 & $0.07 \pm 0.26$ & 0 \\
\hline & Spring & 10 & 0 & $0.40 \pm 0.70$ & $0.10 \pm 0.32$ & $0.40 \pm 0.70$ \\
\hline & Summer & 15 & $0.20 \pm 0.41$ & $0.93 \pm 1.53^{x}$ & $0.20 \pm 0.56$ & $0.33 \pm 0.49$ \\
\hline & Winter & 10 & $0.10 \pm 0.32$ & 0 & $0.10 \pm 0.32$ & 0 \\
\hline \multirow[t]{4}{*}{$\begin{array}{l}\text { Natural } \\
\text { Bank }\end{array}$} & Fall & 12 & $0.21 \pm 0.58$ & $0.07 \pm 0.27$ & $0.07 \pm 0.27$ & $0.21 \pm 0.43$ \\
\hline & Spring & 10 & $0.10 \pm 0.32$ & 0 & 0 & 0 \\
\hline & Summer & 14 & $0.40 \pm 0.74$ & $0.80 \pm 1.61^{x}$ & 0 & $0.07 \pm 0.26$ \\
\hline & Winter & 10 & $0.20 \pm 0.42$ & $0.10 \pm 0.32$ & $0.10 \pm 0.32$ & $0.40 \pm 0.52$ \\
\hline \multirow[t]{4}{*}{$\begin{array}{c}\text { Secondary } \\
\text { Channel }\end{array}$} & Fall & 12 & $0.25 \pm 0.45$ & $0.25 \pm 0.62$ & $0.08 \pm 0.29$ & $0.08 \pm 0.29$ \\
\hline & Spring & 20 & 0 & $0.30 \pm 0.57$ & 0 & $0.05 \pm 0.22$ \\
\hline & Summer & 20 & $0.45 \pm 0.60$ & $1.15 \pm 1.35^{x}$ & 0 & $0.40 \pm 0.68$ \\
\hline & Winter & 10 & $0.20 \pm 0.42$ & 0 & $0.90 \pm 1.37 x$ & $0.40 \pm 1.26$ \\
\hline
\end{tabular}


Table 6. Mean CPUE \pm 1 standard deviation of fish species collected by $4 \mathrm{ft}$ hoopnets in the LMR during 2016 and 2017. Values with letters in the column are significantly $(p<0.05)$ different among seasons within a habitat based on a mixed model ANOVA.

\begin{tabular}{|c|c|c|c|c|c|c|}
\hline Habitat & Season & $\mathbf{N}$ & Blue Catfish & Flathead Catfish & Buffalo & Freshwater Drum \\
\hline ACM & Fall & 11 & 0 & $0.13 \pm 0.35$ & $0.47 \pm 0.52$ & $0.20 \pm 0.41$ \\
\hline & Spring & 10 & 0 & $0.10 \pm 0.32$ & $0.60 \pm 0.52$ & $0.70 \pm 0.82^{x}$ \\
\hline & Summer & 15 & $0.07 \pm 0.26$ & $0.46 \pm 0.52^{\mathrm{x}}$ & $0.53 \pm 0.74$ & $0.20 \pm 0.41$ \\
\hline & Winter & 10 & 0 & 0.00 & $0.90 \pm 0.57$ & $0.10 \pm 0.32$ \\
\hline $\begin{array}{c}\text { Natural } \\
\text { Bank }\end{array}$ & Fall & 12 & 0 & $0.08 \pm 0.28$ & $0.38 \pm 0.65$ & 0 \\
\hline & Spring & 10 & $0.20 \pm 0.42$ & $0.20 \pm 0.63$ & $0.80 \pm 1.14$ & $0.30 \pm 0.67 \times$ \\
\hline & Summer & 15 & $0.13 \pm 0.52$ & $0.13 \pm 0.35$ & $0.47 \pm 0.92$ & $0.07 \pm 0.26$ \\
\hline & Winter & 10 & 0 & 0 & $0.70 \pm 0.95$ & 0 \\
\hline $\begin{array}{c}\text { Secondary } \\
\text { Channel }\end{array}$ & Fall & 11 & $0.09 \pm 0.3$ & $0.09 \pm 0.30$ & $0.82 \pm 0.98$ & $0.18 \pm 0.40$ \\
\hline & Spring & 20 & $0.05 \pm 0.22$ & 0 & $1.00 \pm 1.03$ & $0.30 \pm 0.57 \times$ \\
\hline & Summer & 20 & 0 & 0 & $0.45 \pm 0.69$ & $0.10 \pm 0.31$ \\
\hline & Winter & 10 & 0 & 0 & $0.50 \pm 0.71$ & 0 \\
\hline
\end{tabular}

Bighead Carp were collected only in $4 \mathrm{ft} \mathrm{hoopnets,} \mathrm{and} \mathrm{except} \mathrm{for} \mathrm{one}$ individual, all Silver Carp were collected in $4 \mathrm{ft}$ hoopnets. Bighead Carp abundance was significantly higher in the summer, but no differences occurred among habitats (Table 7). Bighead Carp were not collected during winter and spring. The highest CPUE for any species occurred for Silver Carp during the spring along ACM. However, abundances among habitats were not significantly higher, but were significantly higher in summer and spring. Silver Carp were mostly absent during the fall and completely absent during the winter. 
Table 7. Mean CPUE \pm 1 standard deviation of Asian Carp collected by $4 \mathrm{ft}$ hoopnets in the LMR during 2016 and 2017. Values with letters in the column are significantly $(p<0.05)$ different among seasons within a habitat based on a mixed model ANOVA.

\begin{tabular}{|c|c|c|c|c|}
\hline Habitat & Season & N & Bighead Carp & Silver Carp \\
\hline ACM & Fall & 15 & 0 & 0 \\
\hline & Spring & 10 & 0 & $2.10 \pm 1.91^{x}$ \\
\hline & Summer & 15 & $0.13 \pm 0.35$ & $1.07 \pm 1.44^{y}$ \\
\hline & Winter & 10 & 0 & 0 \\
\hline Natural Bank & Fall & 13 & 0 & $0.23 \pm 0.44$ \\
\hline & Spring & 10 & 0 & $0.8 \pm 1.32$ \\
\hline & Summer & 15 & $0.20 \pm 0.56$ & $1.53 \pm 2.53^{x}$ \\
\hline & Winter & 10 & 0 & 0 \\
\hline & Fall & 11 & 0 & 0 \\
\hline & Spring & 20 & $0.05 \pm 0.22$ & $1.15 \pm 2.16^{\mathrm{x}}$ \\
\hline & Summer & 20 & $0.40 \pm 0.88$ & $1.85 \pm 2.68^{y}$ \\
\hline & Winter & 10 & 0 & 0 \\
\hline
\end{tabular}

Mean lengths for each species were highest in $4 \mathrm{ft}$ hoopnets given the larger hoop and mesh size (Table 8). Several notable observations were derived from the length table. Smaller (475 millimeter [mm]) bigmouth buffalo were collected in the secondary channel, and juvenile Blue Catfish, Freshwater Drum, and River Carpsucker were common along natural banks and occasionally ACM. The largest individuals of seven species were collected in the secondary channel including Bighead Carp (1060 mm), Buffalo (732-952 mm, depending on species), Blue Sucker $(766 \mathrm{~mm})$, and White Bass (491 mm). The largest Flathead Catfish (1095 mm) was collected along ACM during the summer. 
Table 8. Mean length (millimeter) of fish species collected in the LMR, 2016-2107. All values are total length except Shovelnose Sturgeon (fork length) and Paddlefish (eye-to-fork length).

\begin{tabular}{|c|c|c|c|c|c|c|c|c|}
\hline \multirow[b]{2}{*}{ Species } & \multicolumn{4}{|c|}{ HN3 } & \multicolumn{4}{|c|}{ HN4 } \\
\hline & $\mathrm{N}$ & ACM & $\begin{array}{c}\text { Natural } \\
\text { Bank }\end{array}$ & $\begin{array}{c}\text { Secondary } \\
\text { Channel }\end{array}$ & $\mathrm{N}$ & $\mathrm{ACM}$ & $\begin{array}{c}\text { Natural } \\
\text { Bank }\end{array}$ & $\begin{array}{c}\text { Secondary } \\
\text { Channel }\end{array}$ \\
\hline American eel & 4 & 671 & 593 & 621 & & & & \\
\hline Bighead carp & & & & & 14 & 907 & 905 & 947 \\
\hline Bigmouth buffalo & 4 & & 519 & 475 & 21 & 539 & 567 & 616 \\
\hline Black buffalo & 2 & 583 & & 640 & 9 & 735 & 661 & 792 \\
\hline Blue catfish & 29 & 197 & 264 & 329 & 6 & 627 & 427 & 424 \\
\hline Blue sucker & 2 & 241 & & 710 & 4 & 658 & 630 & 766 \\
\hline Channel catfish & 11 & 501 & & 393 & 6 & 601 & 716 & 107 \\
\hline Common Carp & 2 & 586 & & & 5 & 794 & & 617 \\
\hline Flathead catfish & 64 & 566 & 570 & 528 & 16 & 826 & 697 & 742 \\
\hline Freshwater drum & 31 & 379 & 263 & 443 & 28 & 486 & 499 & 499 \\
\hline Gizzard shad & 11 & 202 & 330 & & 7 & 421 & 419 & 170 \\
\hline Goldeye & 4 & 211 & 208 & & & & & \\
\hline Grass carp & 2 & & & 944 & 4 & 958 & & 889 \\
\hline Highfin carpsucker & 1 & & 289 & & 5 & & 339 & \\
\hline Longear sunfish & 1 & & & 123 & & & & \\
\hline Longnose gar & 7 & 729 & 775 & 1052 & & & & \\
\hline Mooneye & 1 & & & 134 & & & & \\
\hline Paddlefish & & & & & 1 & 885 & & \\
\hline River carpsucker & 3 & & 141 & 333 & 16 & 436 & 475 & 386 \\
\hline Sauger & 1 & 243 & & & & & & \\
\hline Shortnose gar & 4 & 600 & & 613 & & & & \\
\hline Shovelnose sturgeon & 1 & & & 490 & 1 & & & 813 \\
\hline Silver carp & 1 & & & 791 & 128 & 802 & 801 & 815 \\
\hline Smallmouth buffalo & 10 & 545 & 428 & 519 & 70 & 513 & 504 & 525 \\
\hline White bass & 8 & 336 & 345 & 338 & 10 & 428 & 391 & 308 \\
\hline White crappie & 2 & 310 & & 200 & & & & \\
\hline
\end{tabular}




\section{Decadal comparison}

The benthic fish assemblage in terms of numerically dominant species was similar between the two decades based on $3 \mathrm{ft}$ hoopnet catches in summer and fall (4 $\mathrm{ft}$ hoopnets were not used in 1985). In the 1985 study, Flathead Catfish were most abundant (36\% of total individuals), followed by Blue Catfish (28\%) and Freshwater Drum (22\%). In the 2016-17 study, the order of abundance was the same with slight differences in percentages: Flathead Catfish (31\%), Blue Catfish (22\%), and Freshwater Drum (10\%). Species richness was different with a total of 12 species collected in 2016-17 compared to 7 species in 1985. Species that were collected in 2016-17 but not in 1985 were Longnose Gar, Smallmouth Buffalo, Blue Sucker, River Carpsucker, Goldeye, and White Bass. Only the Freshwater Eel was collected in the summer-fall of 1985 and not in 2016-17, although this species was collected in other seasons during the present study. Some discrepancies may have been due to different sample sizes ( $\mathrm{n}=40$ in 1985 versus $n=59$ in 2016-17).

Considering the most abundant species, Blue Catfish CPUE along ACM in 1985 was almost double that of other habitats and decades (Figure 4). Conversely, Flathead Catfish CPUE was twice as high along ACM in 2017. Freshwater Drum abundance tended to decrease between 1985 and 2016-17 and was lowest on natural banks. Gizzard shad were either absent or in low abundance along natural banks in both decades but were commonly collected along ACM.

Asian Carp were rarely caught in the 1980s. Pugh and Schramm (1998) sampled the LMR with $4 \mathrm{ft}$ hoopnets in August-December 1994 and caught only one Bighead Carp and no Silver Carp. Considering the high catch rate of Silver Carp in the 2016-17 study, population expansion of these invasive species occurred over the past 20 years. 
Figure 4. Comparison of mean CPUE (overnight sets of hoopnets) of fish in the LMR between 1985 ( $n=10$ each habitat) and 2016-2017 ( $n=15$ for ACM and $n=14$ for Natural Banks).

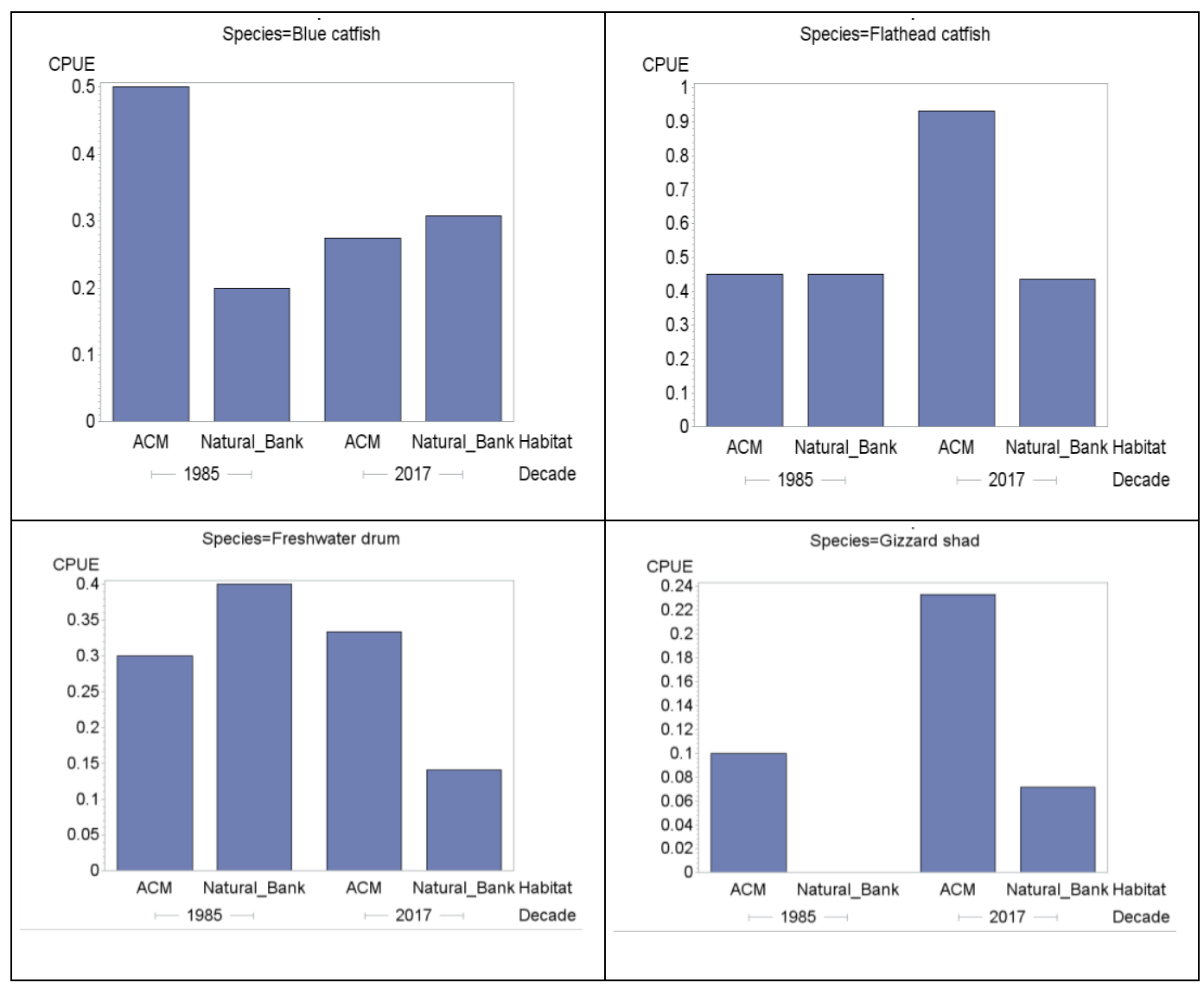




\section{Summary and Recommendations}

Bank stabilization is required for flood risk management and maintenance of river channels for commercial navigation. Eroding banks may impact nearby levees, result in unwanted adjustments in channel alignment, and lead to greater accretion of sediments requiring dredging or addition of other river training structures (Pokrefke 2012). Large rivers, such as the LMR, pose greater challenges because of the magnitude and duration of high water that erodes banks and threatens the infrastructure of the MR\&T, which is the largest flood risk management and navigation project in US Army Corps of Engineers. The advent of ACM to stabilize banks was a significant step forward in river management because of its feasibility, measured in terms of cost effectiveness and its sustainability to withstand major fluctuations in river stages with reduced maintenance for the life of the project. The success of ACM is exemplified by its widespread use in the LMR, in which it encompasses almost 1,00o miles of river bank (Benjamin et al. 2016). However, conversion of natural banks to hardened structures has impacts to the aquatic fauna inhabiting these types of habitats.

Benthic fish represent an important group of obligate riverine species that utilize different substrates and banklines as they search for food and move throughout the river system. It is assumed that their bottom-oriented behaviors make them sensitive to changes in substrates or river bank characteristics. However, the hoopnet study in 1985 by Baker et al. (1988) revealed minimal differences between revetted and natural banks. The follow up study in 2016-17 using the same type of hoopnets ( $3 \mathrm{ft}$ diameter) had similar results in terms of the dominant species collected but differed in seasonal habitat associations.

Flathead Catfish are apex predators in the LMR and demonstrated an affinity to ACM during summer 2017. Blue Catfish, also apex predators, were rarely captured along ACM in 2016-17 and were mostly associated with natural banks and secondary channels, particularly young-of-year life stages. Conversely, Blue Catfish were abundant on ACM in the 1985 study, indicative of the generalist behaviors of large, predatory catfishes. Larger catfishes were captured along ACM where Gizzard Shad, their primary food resource (Eggleton and Schramm 2004), were relatively abundant. Although water velocities are generally higher along ACM, large catfishes and apparently Gizzard Shad co-occur at these locations providing foraging habitat for a large component of the fish assemblage. 
Secondary channels were not sampled during the 1985 study. In the present study, secondary channels were highly utilized by Buffalo and Freshwater Drum during the winter, and juveniles of Blue Catfish and Buffalo were more common in secondary channels and to a lesser degree, natural banks. These results indicate the importance of secondary channels as over-wintering areas to avoid stronger currents along ACM and natural banks in the main channel and for rearing habitat for juvenile life stages in spring and summer. Overall, species richness was highest in secondary channels (21 species) based on both sizes of hoopnets, compared to ACM (20 species) and natural banks (16 species).

Similarity in species richness among the three bank habitats suggests that benthic fishes are widespread in the LMR. Most species are bottomoriented habitat generalists found along a variety of bank types and, based on the comparison with the 1985 data, the assemblage exhibits both stability in the dominant taxa (Catfishes, Buffaloes, and Freshwater Drum) and long-term resilience in the overall community structure (Ross et al. 1985). Despite the extensive coverage of ACM in the LMR, the availability of diverse bank habitats, prevalence of connected secondary channels, and the annual connection of the channel with the remaining floodplain continue to support a diverse fish assemblage and may offset adverse impacts of revetted banks.

With these characteristics and the results obtained during this study, benthic fishes may not be an ideal group to differentiate preferences or impacts of riverbank alterations. Additional studies are warranted to continue evaluating other components of the river bank environment including aquatic macroinvertebrates with characteristically limited aquatic dispersal abilities compared to fishes, as well as better defined habitat affinities. Diet studies linking foraging habitat with fish utilization will also provide a more complete understanding of the potential impacts of armoring river banks on aquatic resources.

The prevalence of Asian Carp in the collections was anticipated, along with their overwhelming abundance during certain time periods. Asian carp were not collected during the 1985 study using $3 \mathrm{ft} \mathrm{hoopnets.} \mathrm{Only} \mathrm{one}$ Silver Carp was collected in $3 \mathrm{ft}$ hoopnets during the 2016-17 study whereas 14 Bighead Carp and 138 Silver Carp were collected with $4 \mathrm{ft}$ hoopnets. Asian Carp were introduced into the LMR basin in 1973 for control of algal blooms in aquaculture ponds (Starling 1993). Therefore, it 
is doubtful that Asian Carp occurred in the LMR at any measurable abundance in the $198 \mathrm{os}$, but the use of only $3 \mathrm{ft}$ hoopnets prevents a direct comparison. Not only were Asian Carp collected in all three habitats during the 2016-17 study, they were the most abundant fishes in spring and summer likely associated with spawning movements. Bighead and Silver Carp exhibit protracted, incremental spawning in flowing water generally between April to July (Deters et al. 2013) and apparently move along the bankline before and during spawning movements where they are readily caught with hoopnets. Their influence on native benthic fishes is unknown, but Asian Carp likely will compete for food and space, which could impact the stability and resilience of obligate riverine species native to the LMR. 


\section{References}

Azim M. E. 2009. "Photosynthetic Periphyton and Surfaces." Encyclopedia of Inland Waters. Edited by G. E. Likens, 184-191. Boston, MA: Elsevier Publishers.

Baker, John A., Richard L. Kasul, C. Rex Bingham, Richard E. Coleman, C. H. Pennington, and Linda A. Winfield. 1988. An Ecological Investigation of Revetted and Natural Bank Habitats in the Lower Mississippi River. Lower Mississippi Environmental Program, Report 9. Vicksburg, MS: USACE Mississippi Valley Division.

Benjamin, G. L., Angeline. J. Rodgers, and K. Jack Killgore. 2016. "Mississippi River Ecosystem Restoration: The Past Forty-Plus Years.” Edited by Y. Chen, D. C. Chapman, J. R. Jackson, D. Chen, Z. Li, K. J. Killgore, Q. Phelps, and M. A. Eggleton. Fisheries Resources, Environment, and Conservation in the Mississippi and Yangtze (Changjiang) River Basins, American Fisheries Society, Symposium 84, Bethesda, MD.

Clarke K. R., and R. N. Gorley. 2015. PRIMER v7: User Manual/Tutorial. $7^{\text {th }}$ ed. PRIMER-E. Plymouth, UK.

DeLonay, A. J., K. A. Chojnacki, R. B. Jacobson, J. L. Albers, P. J. Braaten, E. A. Bulliner, C. M. Elliott, S. O. Erwin, D. B. Fuller, J. D. Haas, H. L. A. Ladd, G. E. Mestl, D. M. Papoulias, and M. L. Wildhaber. 2016. Ecological Requirements for Pallid Sturgeon Reproduction and Recruitment in the Missouri River-A Synthesis of Science, 2005 to 2012. Scientific Investigations Report 2015-5145. http://dx.doi.org/10.3133/sir20155145

Deters, J. E., D. C. Chapman, and B. McElroy. 2013. "Location and Timing of Asian Carp Spawning in the Lower Missouri River." Environmental Biology of Fishes 96(5): 617-629.

Eggleton, M. A., and H. L. Schramm. 2004. "Feeding Ecology and Energetic Relationships with Habitat of Blue Catfish, Ictalurus furcatus, and Flathead Catfish, Pylodictis olivaris, in the Lower Mississippi River, U.S.A.” Environmental Biology of Fishes 70: 107-121.

Goodsell, P. J., and S. D. Connell. 2002. "Can Habitat Loss Be Treated Independently of Habitat Configuration? Implications for Rare and Common Taxa in Fragmented Landscapes." Marine Ecology Progress Series 239: 37-44.

Killgore, K. J., P. Hartfield, T. Slack, R. Fischer, D. Biedenharn, B. Kleiss, J. Hoover, and A. Harrison. 2014. Conservation Plan for the Interior Least Tern, Pallid Sturgeon, and Fat Pocketbook Mussel in the Lower Mississippi River (Endangered Species Act, Section 7(a)(1)). MRG\&P Report No. 4. Vicksburg, MS: US Army Engineer Research and Development Center.

Maceina, M. J., P. W. Bettoli, and D. R. DeVries. 1994. "Use of a Split-Plot Analysis of Variance Design for Repeated-Measures Fishery Data." Fisheries 19: 14-20. 
Pokrefke, T. J. 2012. Inland Navigation Channel Training Works. Prepared by the Task Committee on Inland Navigation of the Waterways Committee of the Coasts, Oceans, Ports, and Rivers Institute of the American Society of Civil Engineers. ASCE Manuals and Reports on Engineering Practice No. 124. Reston, VA: American Society of Civil Engineers.

Pugh, L. L., and H. L. Schramm. 1998. "Comparison of Electrofishing and Hoopnetting in Lotic Habitats of the Lower Mississippi River." North American Journal of Fisheries Management 18(3): 649-656.

Ross, S. T., W. J. Matthews, and A. A. Echelle. 1985. "Persistence of Stream Fish Assemblages: Effects of Environmental Change." The American Naturalist 126 (1): $22-40$.

Starling, F. L. 1993. "Control of Eutrophication by Silver Carp (Hypophthalmichthys molitrix) in the Tropical Paranoa (Brasilia, Brazil): A Mesocosm Experiment." Hydrobiologia 257: 143-152.

USFWS (U.S. Fish and Wildlife Service). 2013. Biological Opinion: Channel Improvement Program, Mississippi River and Tributaries Project, Lower Mississippi River. Prepared by Mississippi Field Office, USFWS. Jackson, MS: USFWS.

Wondzell, S. M., and P. A. Bisson. 2003. "Influence of Wood on Aquatic Biodiversity." The Ecology and Management of Wood in World Rivers. Edited by S. Gregory, K. Boyer, and A. Gurnell, 249-263. American Fisheries Society Symposium 37, Bethesda, MD. 


\section{Unit Conversion Factors}

\begin{tabular}{|l|l|l|}
\hline Multiply & By & To Obtain \\
\hline acres & $4,046.873$ & square meters \\
\hline degrees Fahrenheit & $(\mathrm{F}-32) / 1.8$ & degrees Celsius \\
\hline fathoms & 1.8288 & meters \\
\hline feet & 0.3048 & meters \\
\hline hectares & $1.0 \mathrm{E}+04$ & square meters \\
\hline $\begin{array}{l}\text { horsepower (550 foot-pounds force per } \\
\text { second) }\end{array}$ & 745.6999 & watts \\
\hline inches & 0.0254 & meters \\
\hline miles (nautical) & 1,852 & meters \\
\hline miles (U.S. statute) & $1,609.347$ & meters \\
\hline yards & 0.9144 & meters \\
\hline
\end{tabular}




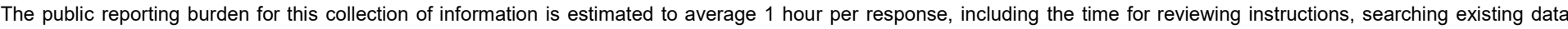

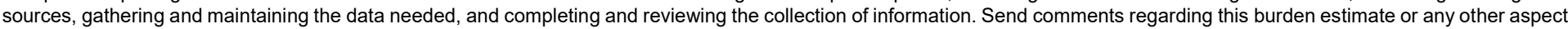

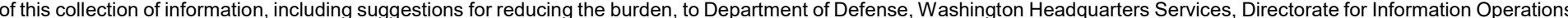

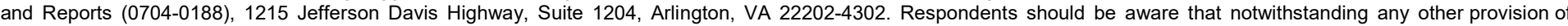
law, no person shall be subject to any penalty for failing to comply with a collection of information if it does not display a currently valid OMB control number. PLEASE DO NOT RETURN YOUR FORM TO THE ABOVE ADDRESS.

\begin{tabular}{l|l}
$\begin{array}{l}\text { 1. REPORT DATE } \\
\text { January } 2020\end{array}$ & $\begin{array}{l}\text { 2. REPORT TYPE } \\
\text { Final Report }\end{array}$ \\
\hline $\begin{array}{l}\text { 4. TITLE AND SUBTITLE } \\
\text { Comparison of Benthic Fish Assemblages along Revetted and Natural Banks in the Lower } \\
\text { Mississippi River: A 30-Year Perspective }\end{array}$
\end{tabular}

3. DATES COVERED (From - To)

5a. CONTRACT NUMBER

5b. GRANT NUMBER

5c. PROGRAM ELEMENT NUMBER

\section{AUTHOR(S)}

K. Jack Killgore and Steven G. George

\section{5d. PROJECT NUMBER}

5e. TASK NUMBER

5f. WORK UNIT NUMBER

8. PERFORMING ORGANIZATION REPORT NUMBER

Environmental Laboratory

US Army Engineer Research and Development Center

3909 Halls Ferry Road

Vicksburg, MS 39180-6199

\section{SPONSORING/MONITORING AGENCY NAME(S) AND ADDRESS(ES)}

US Army Corps of Engineers

MRG\&P Report No. 29

Mississippi Valley Division

Vicksburg, MS 39180
10. SPONSOR/MONITOR'S ACRONYM(S)

USACE MVD

\section{SPONSOR/MONITOR'S} REPORT NUMBER(S)

\section{DISTRIBUTION/AVAILABILITY STATEMENT}

Approved for public release; distribution is unlimited.

\section{SUPPLEMENTARY NOTES}

\section{WAT 2019-3478}

\section{ABSTRACT}

Benthic fish assemblages were compared in 2016-2017 among three different bank types in the Lower Mississippi River (LMR) using hoopnets: Articulated Concrete Mattress (ACM) along main channel banks, natural banks along main channel, and natural banks in a secondary channel. Species richness was highest in secondary channels ( 21 species), followed by ACM ( 20 species), and natural banks (16 species). However, abundance of dominant species (i.e., Flathead Catfish, Blue Catfish, Freshwater Drum, and Buffalo) differed seasonally. Blue Catfish were more abundant along natural banks and secondary channels during the summer. Flathead Catfish abundance peaked during the summer in the secondary channels but were also abundant along ACM year-round. Freshwater Drum abundance was highest along natural banks in the winter and ACM in the spring. Juvenile Buffalo utilized secondary channels in the winter indicating the importance of these habitats for over-wintering fishes. Comparison of the native benthic fish assemblage between 1985 and 201617 revealed minimal differences in species composition and abundance indicating long-term stability and resilience of LMR fishes. An exception was the prevalence of Asian Carp (Silver and Bighead), which were two to three times higher than any native species.

\section{SUBJECT TERMS}

Benthos-Mississippi River, Embankments, Fish populations-Mississippi River, Flood control, River engineering, Stream ecology

\section{SECURITY CLASSIFICATION OF:}

\begin{tabular}{|l|c|l|}
\hline a. REPORT & b. ABSTRACT & c. THIS PAGE \\
Unclassified & Unclassified & Unclassified \\
\hline
\end{tabular}

17. LIMITATION OF ABSTRACT

SAR
18. NUMBER OF PAGES

33 19a. NAME OF RESPONSIBLE PERSON K. Jack Killgore

19b. TELEPHONE NUMBER (Include area code) 601-634-3397 